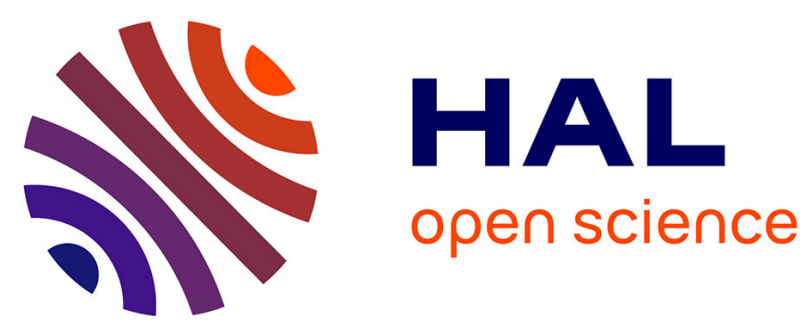

\title{
Investigations in the ternary \\ praseodymium-boron-carbon system: Solid-state phase diagram and structural chemistry
}

\author{
Volodymyr Babizhetskyy, Arndt Simon, Jean-François Halet
}

\section{To cite this version:}

Volodymyr Babizhetskyy, Arndt Simon, Jean-François Halet. Investigations in the ternary praseodymium-boron-carbon system: Solid-state phase diagram and structural chemistry. Solid State Sciences, 2015, Special Issue: International Symposium on Boron, Borides and Related Materials, ISBB 2014, Honolulu, Hawaii, 47, pp.73-77. 10.1016/j.solidstatesciences.2014.12.008 hal-01220892

HAL Id: hal-01220892

https://hal-univ-rennes1.archives-ouvertes.fr/hal-01220892

Submitted on 28 Oct 2015

HAL is a multi-disciplinary open access archive for the deposit and dissemination of scientific research documents, whether they are published or not. The documents may come from teaching and research institutions in France or abroad, or from public or private research centers.
L'archive ouverte pluridisciplinaire HAL, est destinée au dépôt et à la diffusion de documents scientifiques de niveau recherche, publiés ou non, émanant des établissements d'enseignement et de recherche français ou étrangers, des laboratoires publics ou privés. 


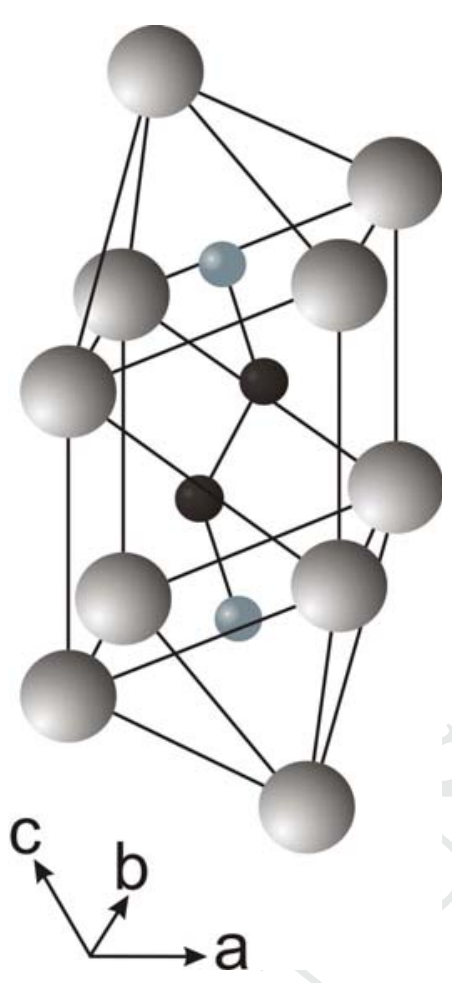




\section{Investigations in the ternary praseodymium - boron - carbon system: Solid- state phase diagram and structural chemistry}

Volodymyr Babizhetskyy ${ }^{a, b, *}$, Arndt Simon ${ }^{a}$, and Jean-François Halet ${ }^{c, *}$

${ }^{a}$ Max-Planck-Institut für Festkörperforschung, Heisenbergstrasse 1, Postfach 800665,

D-70569 Stuttgart, Germany

${ }^{b}$ Department of Inorganic Chemistry, Ivan Franko National University of Lviv,

Kyryla \& Mefodiya Str. 6, UA-79005 Lviv, Ukraine

${ }^{c}$ Institut des Sciences Chimiques de Rennes, UMR 6226 CNRS - Université de Rennes 1, Avenue du Général Leclerc, F-35042 Rennes, France

\section{Abstract}

The solid-state phase equilibrium in the Pr-B-C system was established using X-ray diffraction, scanning electron microscopy and electron probe microanalysis. The region up to 60 at. \% of $\operatorname{Pr}$ was studied at $1270 \mathrm{~K}$, whereas the Pr-rich corner, due to the generally lower melting points, was investigated at $1070 \mathrm{~K}$. Eleven ternary compounds were isolated. The existence of $\operatorname{PrB}_{2} \mathrm{C}_{2}$, $\operatorname{Pr}_{5} \mathrm{~B}_{2} \mathrm{C}_{5}, \operatorname{Pr}_{5} \mathrm{~B}_{4} \mathrm{C}_{5}, \operatorname{Pr}_{5} \mathrm{~B}_{2} \mathrm{C}_{6}, \operatorname{PrBC}$, and $\operatorname{Pr}_{10} \mathrm{~B}_{9} \mathrm{C}_{12}$ was confirmed. $\operatorname{Pr}_{15} \mathrm{~B}_{6} \mathrm{C}_{20}$ and $\operatorname{Pr}_{25} \mathrm{~B}_{14} \mathrm{C}_{26}$ have been found only in arc-melted alloys. Three new ternary compounds were isolated, namely $\operatorname{Pr}_{2} \mathrm{BC}, \sim \operatorname{Pr}_{4} \mathrm{~B}_{3} \mathrm{C}_{13}$ and $\sim \operatorname{Pr}_{7} \mathrm{~B}_{9} \mathrm{C}_{34}$. The monoclinic structure of $\operatorname{Pr}_{2} \mathrm{BC}$ was solved from X-ray single crystal data: space group $C 2 / m(a=13.088(1) \AA, b=3.6748(8) \AA, c=9.488(1) \AA, \beta=$ $131.03(1)^{\circ}, R 1=0.035(\mathrm{w} R 2=0.086)$ for 585 reflections with $\left.I_{\mathrm{o}}>2 \sigma\left(I_{\mathrm{o}}\right)\right)$. Additionally, the phase of $\operatorname{Pr}_{5} \mathrm{~B}_{2} \mathrm{C}_{6}$ was analyzed showing a broad homogeneity range described by the formula $\operatorname{Pr}_{5}(\mathrm{BC})_{\mathrm{x}}(7.5 \leq x \leq 9.3)$.

Keywords: Boride $\bullet$ Borocarbide $\bullet$ Carbide $\bullet$ Crystal structure $\bullet$ Phase diagram Praseodymium

\footnotetext{
* Corresponding authors

E-mail addresses: v.babizhetskyy@googlemail.com (V.B.) and halet@univ-rennes1 (J.-F. H.)
} 


\section{Introduction}

The solid-state chemistry of the ternary rare-earth metal $(R E)$ boride carbides $R E_{\mathrm{x}} \mathrm{B}_{\mathrm{y}} \mathrm{C}_{\mathrm{z}}$ encompasses a variety of different structural arrangements with boron-carbon substructures ranging from zero-dimensional (0-D) units isolated from each other in a matrix formed from the metal atoms to one- and two-dimensional (2-D) networks alternating with metal sub-lattices, which are closely related to the valence electron count (VEC) per light atoms [1-4]. Indeed, nearly a dozen of different structural types have been reported so far solely for the most electronrich compounds, i.e., those containing finite quasi-molecular entities and having a large VEC [14]. These finite chains embedded in voids of the metal atom matrix can have different lengths ranging from 2 to 13 non-metal atoms up to now, and chains of different sizes as well as isolated $\mathrm{C}$ atoms can coexist [5-21]. These compounds were revealed from partial or complete investigations of ternary $R E-\mathrm{B}-\mathrm{C}$ phase diagrams earlier established for most of the rare earth metal elements $(R E=\mathrm{Sc}, \mathrm{Y}, \mathrm{La}, \mathrm{Eu}, \mathrm{Gd}, \mathrm{Ho})$ [22-27]. Novel representatives were recently discovered during our new investigations of the La-B-C [24], Pr-B-C and Nd-B-C systems [20, 21]. Our latest studies of the isothermal sections of the ternary Pr-B-C phase diagram at $1270 \mathrm{~K}$ (concentration range 0-60 at.\% Pr) and $1070 \mathrm{~K}$ (> 60 at.\% Pr), crystallographic data of all the ternary compounds and the structure determinations of the new ternary compound $\operatorname{Pr}_{2} \mathrm{BC}$ and the composition of the solid solution of the phase $\operatorname{Pr}_{5} \mathrm{~B}_{2} \mathrm{C}_{6}$ are the subject of this work.

\section{Experimental}

\subsection{Synthesis and analysis}

Polycrystalline samples were prepared from commercially available pure elements: praseodymium with a claimed purity of 99.99 at $\%$, Alfa - Aesar, Johnson Matthey Company, sublimed bulk pieces; crystalline boron powder, purity 99.99 at\%, H. C. Starck, Germany; graphite powder, purity 99.98 at\%, Aldrich. Before use, the graphite and boron powders were 
out-gased overnight at $1220 \mathrm{~K}, p<10^{-5}$ mbar. Praseodymium ingots were filed to coarse powders with beryllium bronze files (Dönges $\mathrm{GmbH}$, Germany). Stoichiometric mixtures of the constituents were compacted in stainless steel dies. The pellets were arc-melted under purified argon atmosphere [28] on a water-cooled copper hearth. The alloy buttons of $1 \mathrm{~g}$ were turned over and remelted three times to improve homogeneity. The samples were then wrapped in molybdenum foil and annealed in silica tubes under argon for one month at $1270 \mathrm{~K}$ (concentration range 0-60 at.\% $\mathrm{Pr}$ ) or $1070 \mathrm{~K}$ ( $>60$ at.\% Pr). Subsequent heating for some samples just above the melting point was carried out in a high-frequency furnace (TIG-10/300, Hüttinger, FRG) under argon atmosphere for several hours at different temperatures. Finally, the samples were also annealed in evacuated silica tubes for one month by procedure described above and subsequently quenched in cold water. Sample handling was carried out under argon atmosphere in a glove box $\left(P_{\mathrm{H} 2 \mathrm{O}}<0.1 \mathrm{ppm}\right)$ or through the Schlenk technique.

\section{2. $X$-ray diffraction and structure refinement}

X-ray powder diffraction patterns were obtained on a powder diffractometer STOE STADI $P$ with Mo $K_{\alpha 1}$ radiation, using capillaries sealed under dried argon to avoid hydrolysis.

The unit cell parameters for the investigated compounds $\operatorname{Pr}_{x} \mathrm{~B}_{\mathrm{y}} \mathrm{C}_{\mathrm{z}}$, as well as the Rietveld refinements for some samples containing the $\sim \operatorname{Pr}_{5} B_{2} C_{6}$ phase were performed with the help of the CSD programs package [29]. The results are given in Table 1.

Small irregularly shaped single crystals were selected from the crushed sample of $\operatorname{Pr}_{2} \mathrm{BC}$ and sealed under argon atmosphere in glass capillaries. These crystals were first examined by the Buerger precession technique in order to establish their suitability for the subsequent data collection. Single crystal diffraction data of $\operatorname{Pr}_{2} \mathrm{BC}$ were collected at room temperature on a 


\section{ACCEPTED MANUSCRIPT}

STOE IPDS II image plate diffractometer with monochromatized Mo $K_{\alpha}$ radiation. All relevant crystallographic data are listed in Table 2 . The starting atomic parameters were derived

\section{Table 1}

Crystallographic data of ternary compounds in the Pr-B-C system.

\begin{tabular}{|c|c|c|c|c|c|}
\hline \multirow[t]{2}{*}{ Compound } & \multirow{2}{*}{$\begin{array}{l}\text { Space } \\
\text { group }\end{array}$} & \multirow{2}{*}{$\begin{array}{l}\text { Structure } \\
\text { type }\end{array}$} & \multicolumn{3}{|c|}{ Unit cell parameters $(\AA)$} \\
\hline & & & $a$ & $b$ & $C$ \\
\hline 1. $\operatorname{Pr}_{2} \mathrm{BC}$ & $C 2 / m$ & $\mathrm{Nd}_{2} \mathrm{BC}$ & $13.073(1)$ & $\begin{array}{l}3.669(1) \\
\beta=131.01(1)\end{array}$ & $9.486(1)$ \\
\hline 2. $\operatorname{Pr}_{5} \mathrm{~B}_{2} \mathrm{C}_{5}$ & $P 4 / n c c$ & $\mathrm{Gd}_{5} \mathrm{~B}_{2} \mathrm{C}_{5}$ & $8.448(1)$ & & $10.970(2)$ \\
\hline $\begin{array}{l}\text { 3. } \operatorname{Pr}_{5}(\mathrm{BC})_{\mathrm{x}} \\
(7.5 \leq x \leq 9.3)\end{array}$ & $P 4 / n c c$ & $\mathrm{La}_{5} \mathrm{~B}_{2} \mathrm{C}_{6}$ & $\begin{array}{l}8.407(2)- \\
8.403(1)\end{array}$ & & $\begin{array}{l}11.969(4)- \\
12.637(5)\end{array}$ \\
\hline 4. $\operatorname{Pr}_{5} B_{4} C_{5-x}(x=0.15)$ & $\operatorname{Pna}_{1}$ & $\mathrm{Ce}_{5} \mathrm{~B}_{4} \mathrm{C}_{5}$ & $24.592(2)$ & $8.4563(5)$ & $8.4918(5)$ \\
\hline 5. $\operatorname{PrBC}$ & $P 2{ }_{1} 2_{1} 2_{1}$ & $\mathrm{LaBC}$ & $8.4478(5)$ & $8.4719(8)$ & $12.325(1)$ \\
\hline 6. $\operatorname{Pr}_{10} \mathrm{~B}_{9} \mathrm{C}_{12}$ & $P 4_{1} 2_{1} 2$ & $\mathrm{Ce}_{10} \mathrm{~B}_{9} \mathrm{C}_{12}$ & $8.4365(3)$ & & $25.468(1)$ \\
\hline 7. $\operatorname{Pr}_{15} \mathrm{~B}_{6} \mathrm{C}_{20}$ & $P-1$ & $\mathrm{Nd}_{15} \mathrm{~B}_{6} \mathrm{C}_{18}$ & $\begin{array}{l}8.3431(8) \\
\alpha=84.82(1)\end{array}$ & $\begin{array}{l}8.3581(8) \\
\beta=84.23(1)\end{array}$ & $\begin{array}{l}9.2492(9) \\
\gamma=89.68(1)\end{array}$ \\
\hline 8. $\operatorname{Pr}_{25} \mathrm{~B}_{14} \mathrm{C}_{26}$ & $P 2_{1} / \mathrm{n}$ & $\mathrm{Nd}_{25} \mathrm{~B}_{12} \mathrm{C}_{28}$ & $8.4243(5)$ & $8.4095(6)$ & $30.828(1)$ \\
\hline 9. $\mathrm{PrB}_{2} \mathrm{C}_{2}$ & $\mathrm{P} 4 / \mathrm{mbm}$ & $\mathrm{LaB}_{2} \mathrm{C}_{2}$ & $5.38486(4)$ & $p-100.0 / 9(4)$ & $3.8148(6)$ \\
\hline 10. $\sim \operatorname{Pr}_{4} B_{3} C_{13}$ & --- & & 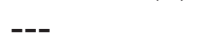 & --- & -- \\
\hline 11. $\sim \operatorname{Pr}_{7} B_{9} C_{34}$ & --- & -- & --- & --- & --- \\
\hline
\end{tabular}

via direct methods using the program SIR97 [30]. They were subsequently refined with the program SHELX-97 [31] within the WinGX program package [32] (full matrix least-squares on $F^{2}$ ) with anisotropic atomic displacement factors for all atoms. No additional reflections with regard to the $\mathrm{Nd}_{2} \mathrm{BC}$ type unit cell were detected. The atomic coordinates and displacement parameters are listed in Table 3.

\subsection{Microprobe analysis}

For metallographic investigation and electron probe microanalysis (EPMA) some alloys were embedded in Woods metal (Fluka Chemie, Switzerland) with a melting point of ca. $75^{\circ} \mathrm{C}$. The samples were polished on a nylon cloth using chromium oxide (Bühler Isomet) suspended in 


\section{Table 2}

Crystal data and structure refinement for $\operatorname{Pr}_{2} \mathrm{BC}$.

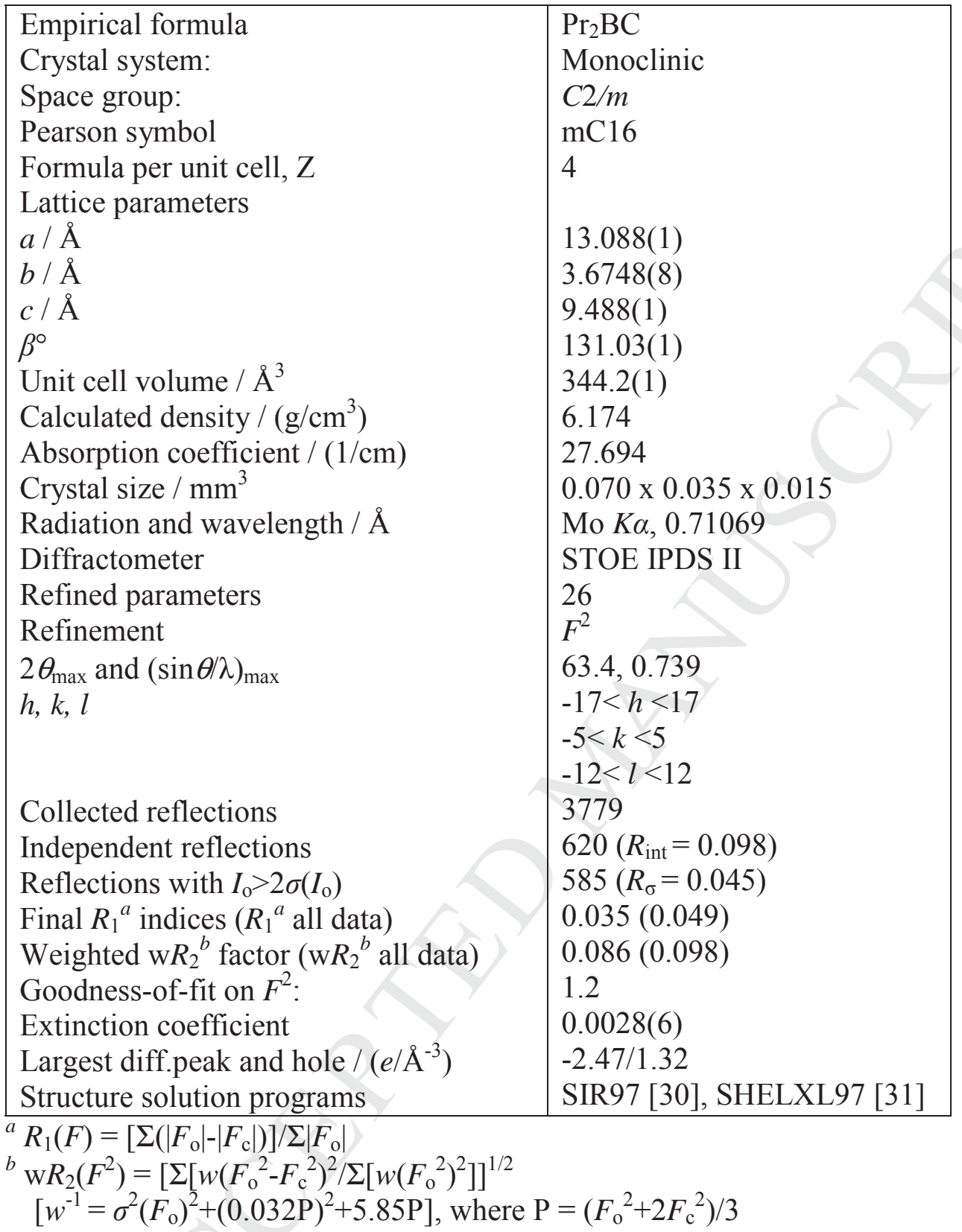

Table 3

Atomic coordinates and displacement parameters ${ }^{a}$ (in $\AA^{2}$ ) for $\operatorname{Pr}_{2} \mathrm{BC}$.

\begin{tabular}{|l|l|l|l|l|l|l|l|l|l|}
\hline Atom & Site & \multicolumn{1}{c|}{$x$} & $y$ & \multicolumn{1}{c|}{$z$} & \multicolumn{1}{c|}{$U_{\mathrm{eq}}$} & \multicolumn{1}{c|}{$U_{11}$} & $U_{22}$ & $U_{33}$ & \multicolumn{1}{c|}{$U_{13}$} \\
\hline Pr1 & $4 i$ & $0.79734(6)$ & 0 & $0.38294(7)$ & $0.0121(6)$ & $0.0186(3)$ & $0.0131(3)$ & $0.0076(3)$ & $0.0063(3)$ \\
\hline Pr2 & $4 i$ & $0.43493(5)$ & 0 & $0.14039(8)$ & $0.0157(3)$ & $0.0223(4)$ & $0.0129(3)$ & $0.0100(3)$ & $0.0056(3)$ \\
\hline C & $4 i$ & $0.875(1)$ & 0 & $0.698(1)$ & $0.021(5)$ & $0.022(5)$ & $0.014(4)$ & $0.007(4)$ & $0.006(3)$ \\
\hline B & $4 i$ & $0.577(1)$ & $1 / 2$ & $0.107(2)$ & $0.029(5)$ & $0.018(5)$ & $0.011(4)$ & $0.011(4)$ & $0.012(4)$ \\
\hline
\end{tabular}


dry petroleum with grain sizes $1-5 \mu \mathrm{m}$. Qualitative and quantitative composition analyses of the samples were performed by energy dispersive X-ray spectroscopy (EDX) and wavelength dispersive X-ray spectroscopy (WDX) on a scanning electron microscope TESCAN 5130 MM with an Oxford Si-detector and with an Oxford INCA WAVE 700 detector. $\mathrm{PrB}_{2} \mathrm{C}_{2}$ standard was used to deduce the compositions of the new compounds. The boron and praseodymium contents were investigated in the alloys. For the chemical microprobe, the polishing procedure had to be performed or repeated just before the measurements and the surface of the samples was protected by dry petroleum. Metallographic and EPMA analyses of the Pr-B-C ternary system reveal the compound $\operatorname{PrB}_{2} \mathrm{C}_{2}$ [33] to be in phase equilibrium with $\operatorname{Pr}_{10} \mathrm{~B}_{9} \mathrm{C}_{12}$ [17] and $\operatorname{Pr}_{5} \mathrm{~B}_{2.6} \mathrm{C}_{6.7}\left(\mathrm{La}_{5} \mathrm{~B}_{2} \mathrm{C}_{6}\right.$ structure type) $[5,14]$ and $\operatorname{PrB}_{4}[34]$ at $1270 \mathrm{~K} \cdot \operatorname{Pr}_{5} \mathrm{~B}_{2} \mathrm{C}_{5}[16]$ is in phase equilibrium with $\operatorname{Pr}_{5} \mathrm{~B}_{1.7} \mathrm{C}_{5.8}$ and $\operatorname{Pr}_{5} \mathrm{~B}_{4} \mathrm{C}_{5}$ [18]. The results of the EPMA for $\operatorname{Pr}_{5}(\mathrm{BC})_{\mathrm{x}}(7.5 \leq x \leq 9.3)$ are listed in Table 4.

\section{Table 4}

Results of EPMA investigation for alloys* $\operatorname{Pr}_{5}(\mathrm{BC})_{\mathrm{x}}(7.5 \leq x \leq 9.3)$.

\begin{tabular}{|c|c|c|c|c|}
\hline Composition & $\begin{array}{l}\text { Lattice parameters } \\
(a, c \text { in } \AA)\end{array}$ & $c / a$ & $V\left(\AA^{3}\right)$ & $\mathrm{B}$, at $\%$ \\
\hline $\operatorname{Pr}_{5} \mathrm{~B}_{1.7} \mathrm{C}_{5.8}{ }^{a}$ & $\begin{array}{l}8.407(2) \\
11.969(4)\end{array}$ & 1.423 & $845.9(7)$ & $14(1)$ \\
\hline $\operatorname{Pr}_{5} \mathrm{~B}_{2.3} \mathrm{C}_{6.5}{ }^{b}$ & $\begin{array}{l}8.405(1) \\
12.498(4)\end{array}$ & 1.487 & $882.9(5)$ & $17(1)$ \\
\hline $\operatorname{Pr}_{5} \mathrm{~B}_{2.6} \mathrm{C}_{6.7}{ }^{c}$ & $\begin{array}{l}8.403(1) \\
12.637(8)\end{array}$ & 1.503 & $891.6(8)$ & $18(1)$ \\
\hline
\end{tabular}

*Phase equilibrium in alloys is also confirmed by $\mathrm{X}$-ray powder investigations:

${ }^{a} \operatorname{Pr}_{5} \mathrm{~B}_{1.7} \mathrm{C}_{5.8}+\operatorname{Pr}_{5} \mathrm{~B}_{2} \mathrm{C}_{5},{ }^{b} \operatorname{Pr}_{5} \mathrm{~B}_{2.3} \mathrm{C}_{6.5}+\operatorname{Pr}_{10} \mathrm{~B}_{9} \mathrm{C}_{12},{ }^{c} \operatorname{PrB}_{2} \mathrm{C}_{2}+\operatorname{Pr}_{5} \mathrm{~B}_{2.6} \mathrm{C}_{6.7}+\operatorname{PrC}_{2}$

\section{Results and discussion}

\subsection{Phase equilibria in the Pr-B-C ternary system}

The isothermal section of the Pr-B-C phase diagram at $1270 \mathrm{~K}$ and $1070 \mathrm{~K}$ is shown in Fig. 1. According to the phase diagram of the boundaries the Pr-B system contains three binary 
boride compounds, i.e., $\operatorname{Pr}_{2} \mathrm{~B}_{5}[35]$ and $\operatorname{PrB}_{4}[34]$ which are formed by peritectic reactions at $\sim 2250$ and $2620 \mathrm{~K}$, respectively, and $\operatorname{PrB}_{6}$ [36] which melts congruently at $2880 \mathrm{~K}$ and exhibits a narrow range of homogeneity [37]. The data of binary phase diagram of the $\mathrm{Pr}-\mathrm{C}$ system was recently assessed [38]. A small range of homogeneity of $\mathrm{Pr}_{2} \mathrm{C}_{3}$ was confirmed [39]. No extension into the ternary domain has been detected for the binary compound " $\mathrm{B}_{4} \mathrm{C}$ " [40-42]. The phase boundary of the Pr-rich liquid was not defined within the ternary system and two annealing temperatures were chosen for achievement of the phase equilibria in the solid state. In addition, the micrograph analysis was unsuccessful because of high sensitivity of some samples against moisture.

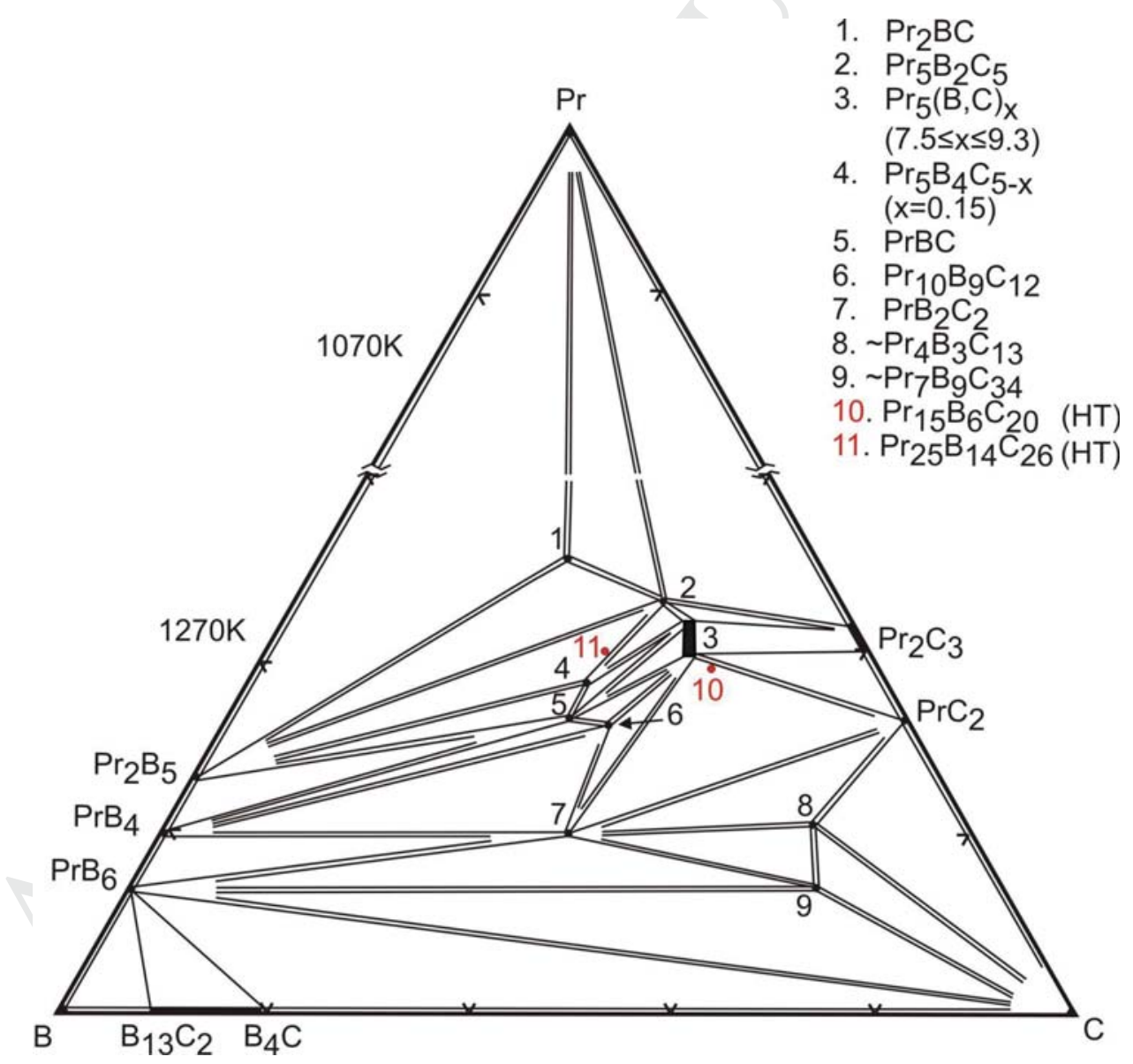

Fig. 1. Isothermal section of the $\mathrm{Pr}-\mathrm{B}-\mathrm{C}$ phase diagram at $1270 \mathrm{~K}$ and $1070 \mathrm{~K}\left(\operatorname{Pr}_{15} \mathrm{~B}_{6} \mathrm{C}_{20}\right.$ and $\operatorname{Pr}_{25} \mathrm{~B}_{14} \mathrm{C}_{26}$ are observed in arc-cast samples). 

new compound $\sim \operatorname{Pr}_{7} B_{9} C_{34}$ to be in equilibrium with $\operatorname{PrB}_{6}$ and $\operatorname{Pr}_{5} B_{2} C_{2}$ (see Fig. 2 a and b). Fig. 2 $\mathrm{c}$ and $\mathrm{d}$ shows the three-phase region of the Pr-B-C ternary system between $\operatorname{PrB}_{2} \mathrm{C}_{2}, \operatorname{Pr}_{5} \mathrm{~B}_{2.6} \mathrm{C}_{6.7}$ and $\operatorname{Pr}_{10} \mathrm{~B}_{9} \mathrm{C}_{12}$ confirmed by refinement of the X-ray powder diffraction data and EPMA analyses.

The crystallographic characteristics of the ternaries in the Pr-B-C system are listed in Table 1. It is worth noting that the phases $\operatorname{Pr}_{15} \mathrm{~B}_{6} \mathrm{C}_{18}$ and $\operatorname{Pr}_{25} \mathrm{~B}_{14} \mathrm{C}_{26}$ were found only in arcmelted alloys. After annealing the samples of the $\operatorname{Pr}_{15} \mathrm{~B}_{6} \mathrm{C}_{20}$ [19] phase at $1270 \mathrm{~K}$, three phases were found in phase equilibrium: $\operatorname{Pr}_{5} \mathrm{~B}_{2} \mathrm{C}_{6}$ [14], $\operatorname{PrB}_{2} \mathrm{C}_{2}$ [33] and $\operatorname{PrC}_{2}$ [43]. After annealing, the phase $\operatorname{Pr}_{25} B_{14} C_{26}$ also had vanished and only $\operatorname{Pr}_{5} B_{2} C_{5}$ [16] and $\operatorname{Pr}_{5} B_{4} C_{5}$ [18] were detected. Finally, three new ternary compounds have been isolated in this system: $\operatorname{Pr}_{2} \mathrm{BC}, \sim \operatorname{Pr}_{4} \mathrm{~B}_{3} \mathrm{C}_{13}$ and $\sim \operatorname{Pr}_{7} \mathrm{~B}_{9} \mathrm{C}_{34}$ characterized both by EPMA and XRD analysis (see Fig. 1).

a)

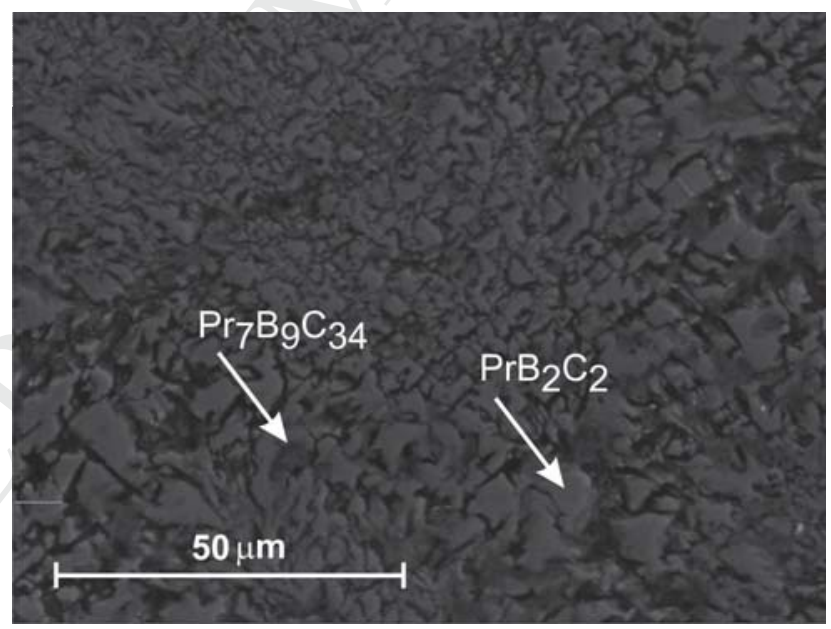

b)

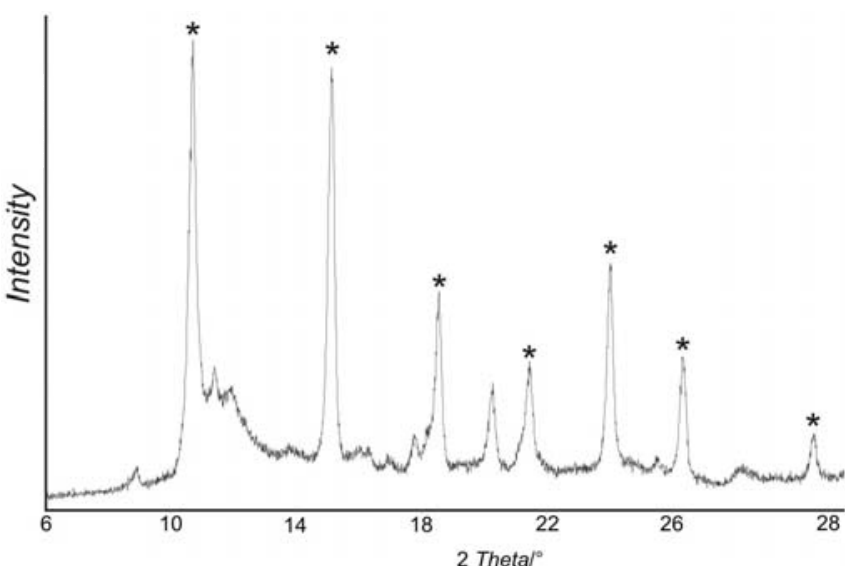




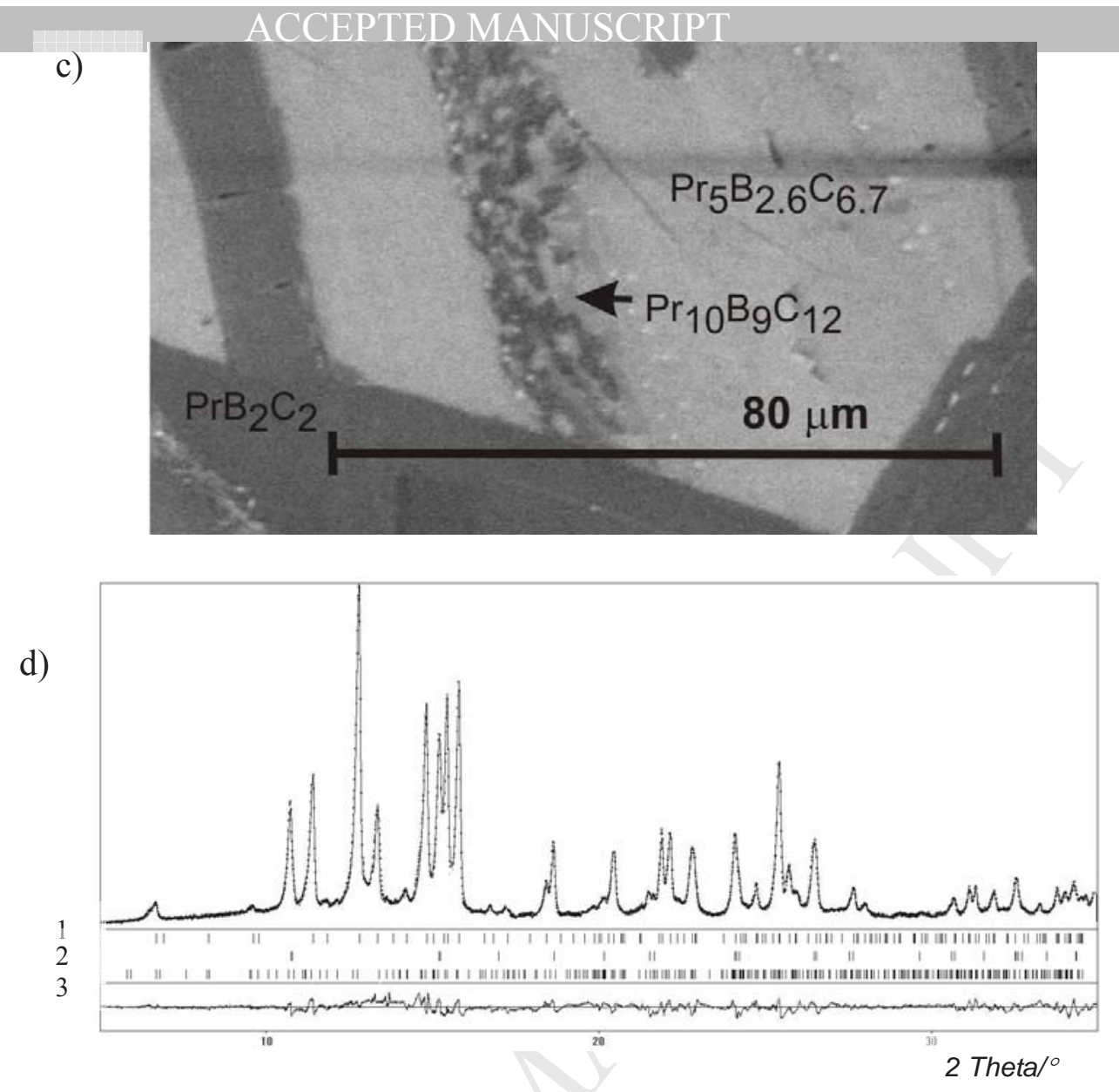

Fig. 2. Secondary electron image (a) and X-ray powder pattern (b) of the annealed bulk sample with nominal atomic composition $\operatorname{Pr} / \mathrm{B} / \mathrm{C}=15 / 25 / 60$. Indicated $(*)$ reflections are from $\operatorname{PrB}_{2} \mathrm{C}_{2}$ and other reflections are from $\sim \operatorname{Pr}_{7} \mathrm{~B}_{9} \mathrm{C}_{34}$. Backscattered electron image (c) and $\mathrm{X}$-ray powder pattern (d) with observed and calculated profiles for $\operatorname{Pr}_{5} B_{2.6} C_{6.7}(1), \operatorname{PrB}_{2} C_{2}(2), \operatorname{Pr}_{10} B_{9} C_{12}$ (3) of the annealed bulk sample with nominal atomic composition $\operatorname{Pr} / \mathrm{B} / \mathrm{C}=30 / 25 / 45$.

\subsection{Crystal structure of $\mathrm{Pr}_{2} \mathrm{BC}$}

Metallographic and EPMA analyses of the Pr-B-C ternary system reveal the new compound $\operatorname{Pr}_{2} \mathrm{BC}$ to be in equilibrium with elemental $\operatorname{Pr}$ and $\operatorname{Pr}_{2} \mathrm{~B}_{5}$ [35] (see Fig.1) or in another sample in equilibrium with $\operatorname{Pr}_{5} \mathrm{~B}_{2} \mathrm{C}_{5}$ [16] and $\operatorname{Pr}$ [44] as well at $1070 \mathrm{~K}$ and at $1270 \mathrm{~K}$ and they are in good agreement with results from X-ray powder diffraction. Our attempts to synthesize isostructural $R E_{2} \mathrm{BC}$ compounds with other rare earth metals (except $\mathrm{Nd}$ ) by the experimental conditions described above were not successful. Indeed, the ternary compound $\operatorname{Pr}_{2} \mathrm{BC}$ crystallizes in the $\mathrm{Nd}_{2} \mathrm{BC}$ structure type, with space group $C 2 / m$ (Fig. 3a), which is closely 
related to the crystal structures of other ternary compounds containing finite isolated boroncarbon chains of different lengths [10]. Contrarily to other known structures the Pr framework adopts a pseudohexagonal symmetry in the [010] direction. The three-dimensional (3-D) framework consists of two different slabs $F$ and $E$, formed from condensed trigonal prisms along the [010] direction. One slab $(F)$ in $\operatorname{Pr}_{2} B C$ is filled by bent $[\mathrm{C}-\mathrm{B}-\mathrm{B}-\mathrm{C}]$ units with distances $\mathrm{d}_{\mathrm{C}-\mathrm{B}}=$ 1.51(1) $\AA, \mathrm{d}_{\mathrm{B}-\mathrm{B}}=1.68(2) \AA$, and C-B-B angle $=133.6(1)^{\circ}$ (see Fig. 3a), comparable to those measured in $\mathrm{Nd}_{2} \mathrm{BC}$ [20]. Such units are also encountered in related compounds such as $\mathrm{La}_{5} \mathrm{~B}_{2} \mathrm{C}_{6}$ [5] and for $\mathrm{Ce}_{6} \mathrm{Br}_{3} \mathrm{~B}_{2} \mathrm{C}_{3}$ [45] for instance. According to the distances and angles measured, a formal charge of 8 - can be suggested for these boron carbon chains, rendering them isoelectronic to 1,3-butadiene. The ionic formulation $\left(\operatorname{Pr}^{3+}\right)_{4}\left(\mathrm{~B}_{2} \mathrm{C}_{2}\right)^{8-} .4$ e- can then be proposed suggesting metallic properties as computed for $\mathrm{Nd}_{2} \mathrm{BC}$ [20]. The boron atoms occupy the center of trigonal prisms of praseodymium atoms. Pr-B distances range from 2.77(1) $\AA$ to 2.903(8) $\AA$ for Pr2 and 2.938(8) A for Pr1. The carbon atoms are located in $\operatorname{Pr}_{5}$ square pyramids with $\operatorname{Pr}-\mathrm{C}$ distances of 2.637(8) $\AA$ (x 4) and 2.44(1) $\AA$ (x 1) (see Fig. 3b). Condensation of two trigonal prisms via a common rectangular face and their opposite capping with square pyramids leads to $\operatorname{Pr}_{10}$ cages embedding the [C-B-B-C] units (see Fig. 3b). The Pr-Pr distances in the slabs containing the $\mathrm{C}_{2} \mathrm{~B}_{2}$ units range from 3.668(1) $\AA$ to 3.994(7) $\AA$. In empty slabs $(E)$ formed only from $\operatorname{Pr}$ atoms (Fig. 3a) and linking both adjacent filled F slabs, Pr-Pr distances are larger than in the filled ones and range from 3.752(1) $\AA$ to 4.195(1) $\AA$. 


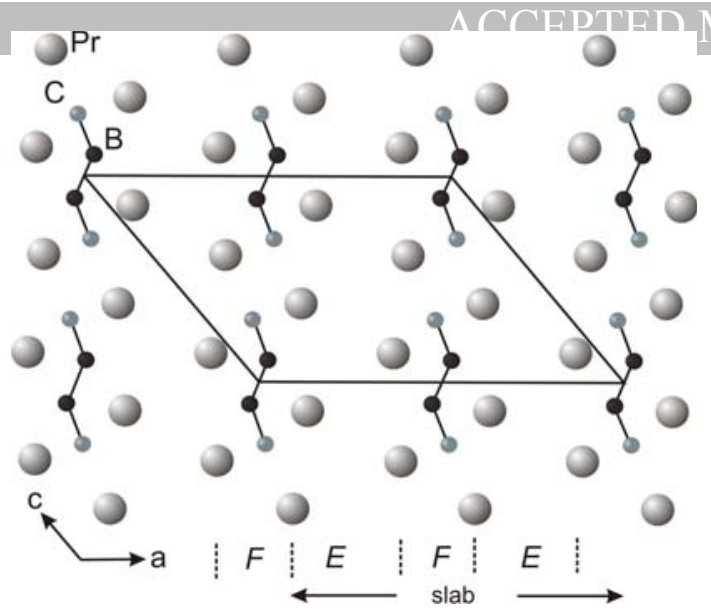

a)

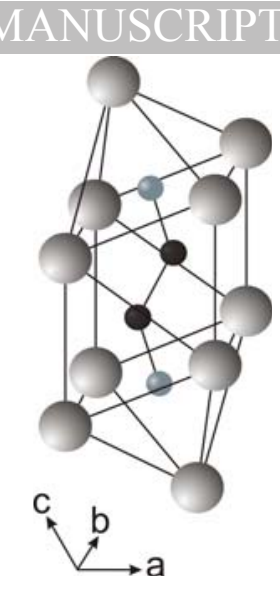

b)

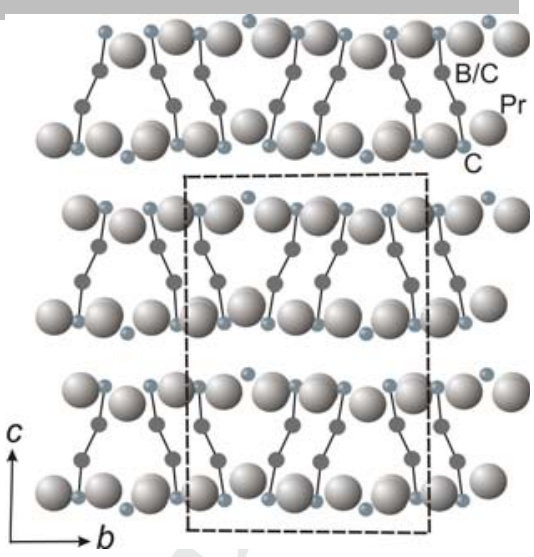

c)

Fig. 3. The crystal structure of $\operatorname{Pr}_{2} B C$ (a), praseodymium environment of $B_{2} C_{2}$ units in $\operatorname{Pr}_{2} B C$ (b), and the crystal structure of $\operatorname{Pr}_{5} \mathrm{~B}_{2} \mathrm{C}_{6}$ (c).

\subsection{Solid solution $\operatorname{Pr}_{5}(B C)_{x}(7.5 \leq x \leq 9.3)$}

The crystal structure, twinning and intergrowth of the samples with different compositions $\sim \operatorname{Pr}_{5} B_{2} C_{6}$ were investigated in $[14,46]$. These samples exhibit a pronounced tendency to form twins and coherently intergrown domains of different phases. A large variation of cell parameters was also evidenced. The structural arrangement of $\sim \operatorname{Pr}_{5} \mathrm{~B}_{2} \mathrm{C}_{6}\left(\mathrm{La}_{5} \mathrm{~B}_{2} \mathrm{C}_{6}\right.$ structure type [5]) consists of a 3-D framework of rare-earth atoms resulting from the stacking of slightly corrugated two-dimensional squares, which leads to the formation of octahedral voids and distorted bicapped square antiprismatic cavities (Fig. 3c). They are filled with isolated carbon atoms and twofold disordered $[\mathrm{CBCC}]$ units, respectively. The $\mathrm{C} 1$ and $\mathrm{C} 2 / \mathrm{B} 2$ atoms in $\sim \operatorname{Pr}_{5} \mathrm{~B}_{2} \mathrm{C}_{6}$ form bent [CBCC] units with $\mathrm{C} / \mathrm{B}-\mathrm{C}$ distances of $1.32 \AA$ indicative of double bond character and $\mathrm{C} / \mathrm{B}-\mathrm{C} / \mathrm{B}$ distances of $1.65 \AA$. The $\mathrm{C}-\mathrm{C} / \mathrm{B}-\mathrm{C} / \mathrm{B}$ angle is $158.1^{\circ}$. Our systematical studies of the similar solid solution $\mathrm{La}_{5} \mathrm{~B}_{2-\mathrm{x}} \mathrm{C}_{6+\mathrm{y}}$ led to the formula $\mathrm{La}_{5}(\mathrm{BC})_{\mathrm{x}}(5.6 \leq x \leq 8.8)$ [24]. Samples with different compositions of $\sim \operatorname{Pr}_{5} \mathrm{~B}_{2} \mathrm{C}_{6}$ exhibit different cell parameters (Table 4). Changes are pronounced depending upon Pr and non-metal atoms stoichiometry and the cell volumes increase from 845.9(7) to 891.6(8) $\AA^{3}$ (Table 4). The results of the Rietveld refinements of XRD powder data are similar to the single crystal structure investigation reported earlier [14, 46]. The atoms in the structure exhibit large displacement parameters for the central $\mathrm{C} / \mathrm{B}$ atoms 
of the $[\mathrm{CBCC}]$ units in line with the disorder of occupation by either $[\mathrm{CBC}]$ or $[\mathrm{CBCC}]$ units for the large voids and single carbon atoms in octahedral voids. This is the reason for the large homogeneity region of this compound. The WDX analysis of the investigated samples shows that the boron content in the anionic chains $[\mathrm{C}=\mathrm{B}-\mathrm{C}=\mathrm{C}]^{7-}$ (assuming the formal charge for the $\mathrm{B} / \mathrm{C}$ atoms to obey the octet rule) of $\sim \operatorname{Pr}_{5} \mathrm{~B}_{2} \mathrm{C}_{6}$ structure varies from 14(1) to $18(1)$ at $\%$ (Table 4 ) which leads to a decrease in charge as well as disorder of light elements. The overall charge of the anionic part seems to be compensated by the introduction of single carbon atoms (C3) in $\operatorname{Pr}$ octahedra. So, the homogeneity region of $\sim \operatorname{Pr}_{5} \mathrm{~B}_{2} \mathrm{C}_{6}$ is defined as $\operatorname{Pr}_{5}(\mathrm{BC})_{\mathrm{x}}(7.5 \leq x \leq 9.3)$ and shown in Fig. 1. The lanthanum compound $\sim \mathrm{La}_{5} \mathrm{~B}_{2} \mathrm{C}_{6}$ exhibits a more pronounced homogeneity region than $\operatorname{Pr}_{5} \mathrm{~B}_{2} \mathrm{C}_{6}$ due to the fact that in the Pr-B-C the other ternary compound $\operatorname{Pr}_{5} \mathrm{~B}_{2} \mathrm{C}_{5}$ also exists.

\section{Conclusion}

The isothermal section of the $\operatorname{Pr}-\mathrm{B}-\mathrm{C}$ phase diagram at $1270 \mathrm{~K}$ and $1070 \mathrm{~K}$ was investigated by means of X-ray diffraction, microstructure and EPMA analyses. Eleven ternary compounds were found. For eighth of them, namely $\operatorname{PrB}_{2} \mathrm{C}_{2}, \operatorname{Pr}_{5} \mathrm{~B}_{2} \mathrm{C}_{5}, \operatorname{Pr}_{5} \mathrm{~B}_{4} \mathrm{C}_{5}, \operatorname{Pr}_{5} \mathrm{~B}_{2} \mathrm{C}_{6}, \operatorname{PrBC}_{\text {, }}$ $\operatorname{Pr}_{10} \mathrm{~B}_{9} \mathrm{C}_{12}, \operatorname{Pr}_{15} \mathrm{~B}_{6} \mathrm{C}_{18}$ and $\operatorname{Pr}_{25} \mathrm{~B}_{14} \mathrm{C}_{26}$, the crystal structures were established previously. Indeed, our studies showed that both phases $\operatorname{Pr}_{15} \mathrm{~B}_{6} \mathrm{C}_{20}$ and $\operatorname{Pr}_{25} \mathrm{~B}_{14} \mathrm{C}_{26}$ exist above $1270 \mathrm{~K}$. We also observed that the $\sim \operatorname{Pr}_{5} \mathrm{~B}_{2} \mathrm{C}_{6}$ compound has a broad homogeneity range described by the formula $\operatorname{Pr}_{5}(\mathrm{BC})_{\mathrm{x}}(7.5 \leq x \leq 9.3)$. For the boundary compounds of the Pr-B and Pr-C system no extension in the ternary domain was found. Three new ternary compounds were isolated, namely $\operatorname{Pr}_{2} \mathrm{BC}$, $\sim \operatorname{Pr}_{4} \mathrm{~B}_{3} \mathrm{C}_{13}$ and $\sim \operatorname{Pr}_{7} \mathrm{~B}_{9} \mathrm{C}_{34}$. The new compound $\operatorname{Pr}_{2} \mathrm{BC}$ crystallizes in $\mathrm{Nd}_{2} \mathrm{BC}$ structure type [20]. In contrast to other rare earth metals with smaller atomic radius, praseodymium boride carbides do not form compounds with infinite one-dimensional planar or nearly planar $(\mathrm{BC})_{\infty}$ ribbons.

Except $\operatorname{PrB}_{2} \mathrm{C}_{2}$, which adopt the $\mathrm{CeB}_{2} \mathrm{C}_{2}$ structure type with 2-D $\mathrm{B} / \mathrm{C}$ nets [33], all the 
investigated structures contain finite (0-D) quasi-molecular linear or bent $\mathrm{B} / \mathrm{C}$ entities of different lengths, which fill voids in praseodymium atom cages.

\section{Acknowledgements}

The authors gratefully thank M. Babizhetska for the sample preparation, H. Gärtling for Xray intensity data collection and V. Duppel for EPMA analysis.

\section{References}

[1] J. Bauer, G. Boucekkine, G. Frapper, J.-F. Halet, J.-Y. Saillard, B. Zouchoune, J. Solid State Chem. 133 (1997) 190.

[2] J. Bauer, J.-F. Halet, J.-Y. Saillard, Coord. Chem. Rev. 178-180 (1998) 723-753 and refs. therein.

[3] (a) J.-F. Halet in Contemporary Boron Chemistry, M. G. Davidson, A. K. Hugues, T. B. Marder, K. Wade (Eds.), Royal Society of Chemistry, Cambridge, 2000, p. 514 and refs. therein. (b) S. Lassoued, R. Gautier, J.-F. Halet in Boron Rich Solids: Sensors, Ultra High Temperature Ceramics, Thermoelectrics, Armor, N. Orlovskaya, M. Lugovy (Eds.), Springer Science and Business Media V. B., 2011, pp. 95 and refs. therein.

[4] M. Ben Yahia, J. Roger, X. Rocquefelte, R. Gautier, J. Bauer, R. Guérin, J.-Y. Saillard, J.-F. Halet, J. Solid State Chem. 179 (2006) 2779 and refs. therein.

[5] (a) J. Bauer, O. Bars, J. Less-Common Met. 83 (1983) 17.

(b) O. Oeckler, J. Bauer, Hj. Mattausch, A. Simon, Z. Anorg. Allg. Chem. 627 (2001) 779.

[6] (a) J.-F. Halet, J.-Y. Saillard, J. Bauer, J. Less-Common Met. 158 (1990) 239.

(b) Y. Shi, A. Leithe-Jasper, T. Tanaka, J. Solid State Chem. 184 (1999) 250.

[7] P. Gougeon, J.-F. Halet, D. Ansel, J. Bauer, Z. Kristallogr. 211 (1996) 822.

[8] (a) P. Gougeon, J.-F. Halet, D. Ansel, J. Bauer, Z. Kristallogr. 211 (1996) 823.

(b) V. Babizhetskyy, H.j. Mattausch, A. Simon, Z. Kristallogr. 219 (2004) 11. 
[9] (a) P. Gougeon, J.-F. Halet, D. Ansel, J. Bauer, Z. Kristallogr. 211 (1996) 824.

(b) V. Babizhetskyy, Hj. Mattausch, A. Simon, Z. Kristallogr. 218 (2003) 417.

[10] J. Bauer, D. Ansel, F. Bonhomme, G. Boucekkine, G. Frapper, P. Gougeon, J.-F. Halet, J.Y. Saillard, B. Zouchoune, Angew. Chem., 108 (1996) 2245; Angew. Chem. Int. Ed. Engl., 35 (1996) 2098.

[11] E. Bidaud, K. Hiebl, R.-D. Hoffmann, R. Pöttgen, C. Jardin, J. Bauer, R. Gautier, P. Gougeon, J.-Y. Saillard, J.-F. Halet, J. Solid State Chem. 154 (2000) 286.

[12] (a) Y. Shi, A. Leithe-Jasper, L. Bourgeois, Y. Bando, T. Tanaka, J. Alloys Compd. 298 (2000) 99.

(b) T. Mori, Y. Shi, T. Tanaka, J. Alloys Compd. 308 (2000) 115.

[13] O. Oeckler, C. Jardin, Hj. Mattausch, A. Simon, J.-F. Halet, J.-Y. Saillard, J. Bauer, Z. Anorg. Allg. Chem. 627 (2001) 1389.

[14] O. Oeckler, Hj. Mattausch, J. Bauer, A. Simon, Z. Naturforsch. 59b (2004) 1551.

[15] V. Babizhetskyy, Hj. Mattausch, A. Simon, R. Gautier, J. Bauer, J.-F. Halet, Z. Anorg. Allg. Chem. 631 (2005) 1041.

[16] V. Babizhetskyy, Hj. Mattausch, A. Simon, Z. Kristallogr. NCS 221 (2006) 1.

[17] V. Babizhetskyy, K. Hiebl, R. K. Kremer, Hj. Mattausch, A. Simon, Solid State Sci. 9 (2007) 1126.

[18] V. Babizhetskyy, K. Hiebl, Hj. Mattausch, A. Simon, J. Phys. Chem. Solids. 70 (2009) 561.

[19] V. Babizhetskyy, Hj. Mattausch, A. Simon, K. Hiebl, M. Ben Yahia, R. Gautier, J.-F. Halet, J. Solid State Chem. 181 (2008) 1882.

[20] V. Babizhetskyy, J. Köhler, Hj. Mattausch, A. Simon, Z. Kristallogr. 226 (2011) 93.

[21] V. Babizhetskyy, Hj. Mattausch, A. Simon, R. Gautier, J.-F. Halet, J. Solid State Chem. 184 (2011) 1671.

[22] Y. Shi, A. Leithe-Jasper, T. Tanaka, J. Solid State Chem. 148 (1999) 250.

[23] J. Bauer, H. Nowotny, Monatsh. Chem. 102 (1971) 1129. 
[24] V. Babizhetskyy, A. Simon, J. Bauer, Monatsh. Chem. 145 (2014) 869.

[25] K. A. Schwetz, M. Hoerle, J. Bauer, Ceramurgia Intl. 5 (3) (1979) 105.

[26] (a) P. K. Smith, P. W. Gilles, J. Inorg. Nucl. Chem. 29 (1967) 375.

(b) D. Ruiz, M. T. Garland, J-Y. Saillard, J.-F. Halet, M. Bohn, J. Bauer Solid State Sci. 4 (2002) 1173.

[27] J. Bauer, P. Vernnegues, J. L. Vergneau., J. Less Comm. Met. 110 (1985) 295.

[28] B. Horvath, J. Strutz, J. Geyer-Lippmann, G. Horvath, Z. Anorg. Allg. Chem. 483 (1981) 205.

[29] L. Akselrud, Y. Grin, J. Appl. Crystallogr. 47 (2014) 803.

[30] A. Altomare, M. C. Burla, M. Camalli, G. L. Cascarano, C. Giacovazzo, A. Guagliardi, A.

G. Giuseppina Moliterni, G. Polidori, R. Spagna, J. Appl. Crystallogr. 32 (1999) 115.

[31] G. M. Sheldrick, SHELXL-97, Program for the Refinement of Crystal Structures, University of Göttingen (Germany) (1997).

[32] L. J. Farrugia, WinGX (Version 1.64.05), J. Appl. Crystallogr. 32 (1999) 837.

[33] K. Onoyama, K. Kaneko, K. Indoh, H. Yamauchi, A. Tobo, H. Onodera, Y. Yamaguchi, J. Phys. Soc. Japan. 11 (70) (2001) 3291.

[34] B. Post, D. Moskowitz, F. W. Glaser, J. Amer. Chem. Soc. 78 (1956) 1800.

[35] Yu. B. Kuz’ma., V. S. Babizhetskyy, R. Guerin, S. I. Mikhalenko, Crystallography Reports. 48(4) (2003) 568.

[36] N. N. Tvorogov, Russ. J. Inorg. Chem. 4 (1959) 890.

[37] K. E. Spear, Boron and Refractory Borides (Springer, Berlin, 1977), p. 439.

[38] Y. Peng, Y. Dua, L. Zhang, C. Sha, S. Liu, F. Zheng, D. Zhao, X. Yuan, L. Chen, CALPHAD 35 (2011) 533.

[39] F. H. Spedding., K. A. Gschneidner Jr, A. H. Daane, J. Am. Chem. Soc. 80 (1958) 4499.

[40] P. F. Rogl, J. Vrestal, T. Tanaka, S. Takenouchi, CALPHAD 44 (2014) 3.

[41] B. Morosin, G. H. Kwei, A. C. Lawson, T. L. Aselage, D. Emin, J. Alloys Compd. 226 (1995) 121. 
[42] O. Sologub, Y. Michiue, T. Mori, Acta Cryst. E68 (2012) i67 and refs therein.

[43] M. Atoji, J. Chem. Phys. 46 (1967) 1891.

[44] P. Villars, L. D. Calvert: Pearson's Handbook of Crystallographic Data for Intermetallic Phases, 2nd ed., ASM, Materials Park, OH, 1991.

[45] Hj. Mattausch, A. Simon, Angew. Chem. Int. Ed. Engl. 34 (1995) 1633.

[46] O. Oeckler, V. Duppel, J. Bauer, Hj. Mattausch, A. Simon, Acta Cryst. B 58 (2002) 161. 


\section{Highlights}

Solid-state phase equilibrium in the Pr-B-C system was established at $1270 \mathrm{~K}$. Eleven ternary compounds were isolated. The monoclinic structure of $\operatorname{Pr}_{2} \mathrm{BC}$ was solved from $\mathrm{X}$ ray single crystal data. The phase of $\operatorname{Pr}_{5} \mathrm{~B}_{2} \mathrm{C}_{6}$ shows a broad homogeneity range. 